\section{TRAINING FOR INDUSTRY AND THE PROFESSIONS}

$\mathrm{T}$ HE 1951 Cantor Lectures on training for industry and the professions have now been published by the Royal Society of Arts (J. Roy. Soc. Arts, 99, No. $4853 ;$ 1951). The series of lectures was introduced by Sir Godfrey Ince, permanent secretary to the Ministry of Labour and National Service, who suggested that the major part of the training for industry and the professions that goes on in Great Britain is done by industry and by the professions themselves, government taking a lesser part.

In dealing with the man-power position in Great Britain, Sir Godfrey indicated that the outstanding feature of the man-power situation to-day is the scarcity of labour, particularly the scarcity of skilled personnel and of young persons.

The shortage of skilled personnel is matched by the shortage of men of science and technicians of professional and semi-professional standards. As rearmament proceeds and the Colombo Plan, which will require many professionally qualified technicians, develops, these shortages will become more acute.

At the same time there are fewer boys and girls available to enter industry and the professions than before the War. Of boys and girls reaching the age of fifteen, there has been a drop in their numbers compared with the situation before the War from 740,000 to 635,000 ; of boys and girls reaching the age of eighteen there has becn a fall from roughly 840,000 to 640,000 . This situation will not begin to improve until 1957 for boys and girls reaching the age of fifteen, nor until 1960 for those reaching the age of eighteen.

In considering the training of young persons, Sir Godfrey declared that all young people should receive an adequate measure of general education, should be given the best possible advice before choosing a career and should be placed in the job which suits him or her best and should be properly and adequately trained for that job.

At present some seventy sections of industry have produced systematic schemes of recruitment and training and have set up machinery which includes a national joint committee or council and local joint committees or panels. The schemes which have been adopted generally cover such matters as methods of recruitment and initiation into industry; ages of recruitment, periods of apprenticeship, and methods of engagement; qualifications for particular occupa. tions ; methods of training, including the preparation of model training schemes providing for progressive training, covering, if need be, arrangements for transfer from employment to employment in the same establishment, or between establishments, to ensure the acquisition of all-round skill by the young workers; supervision during training, both within the firm and by a representative body of the industry ; and further education and technical training.

Many apprenticeship arrangements have recently been improved, but in some industries the period of apprenticeship is still too long and could be reduced. Experience in the Ministry of Labour in its vocational training centres has shown that by intensive training methods a very high dogree of skill can be acquired in a comparatively short time.

Sir Godfrey also said that industry has no systematic schemes of training for adults, although many firms have their own schemes of training both for the purpose of making employees more efficient in their existing jobs and for fitting them for higher jobs. These arrangements are often on an individual basis and are rum in co-operation with educational institutions and, to a lesser extent, with voluntary organizations.

In the professions effective and efficient systems of training have existed for a long time. In Sir Godfrey's view, the professions are fully alive to the need for modifying their arrangements to meet the changed circumstances of the times and of maintaining their high and established standards. Like industry, commerce and the Armed Forces, the professions will all feel the effect of the acute shortage of young persons during the next ten years. The professions, however, are likely to suffer least because of the increasing numbers that are receiving secondary and higher education.

One general problem affects a number of professions - the gap between the school-leaving age and the age of entry into the professions. This question of 'bridging the gap', as it is called, is well known, for example, to the nursing profession. It is essentially a training problem-a problem of pre-entry training. Unless sound schemes of 'earning and learning' during the period between leaving school and being able to start training are introduced by those professions that are affected in this way, they will have increasing difficulty in securing the necessary recruits to train.

Sir Godfrey then reviewed the training given by educational institutions. Education in the schools is not of itself sufficient, and the necessary qualifications have to be obtained by continuing education at technical colleges or universities, or they may be obtained within the professions or industries themselves.

Boys and girls who enter employment immediately on leaving school are often able to continue their education and receive training either on a part-time basis during the day-time, or at evening classes. It is here that technical colleges are so important. In general, technical colleges provide both full-time and part-time education, and the field they cover extends from theoretical education appropriate to apprentices -aiming at becoming skilled craftsmen and perhaps to go no further-to the highest qualified professional, technical and scientific personnel.

Some of the technical colleges have been training men and women for industry and commerce for the past hundred years, and the valuable contribution which they have made to our national industries has not been sufficiently recognized. The past successes of the technical colleges and their beneficial effect on industry have been mainly dependent on the initiative, enterprise, and progressive outlook of the individual students whose tenacity carried them through many years of evening attendance. In 1949, of a tutal of $2,115,000$ students at technical colleges, 50,000 were full-time, 265,000 part-time, and no less than $1,800,000$ were evening students.

In recent years there has been a much greater appreciation by industry and commerce of the value of technical education. In 1949, for example, about 85 per cent of the part-time students were released by their employers during working hours. While much credit is due to industry for the more enlightened view taken recently, the extent of part-time release is still relatively small and much remains to be done.

The link between education and industry, commerce, and the professions in the field covered by 
technical colleges is of vital importance; wherever industries are to be developed, technical education at all grades is essential. In the apprenticeship field it is most important that the syllabus of instruction in technical training should be closely related to the practical training the apprentice is receiving in his work. The same is true in the higher ranges. As an example of the close collaboration which to-day exists between industry and education, and which should be developed whenever possible, it is worth noting that much of the part-time education is carried on by teachers normally employed in industry.

After considering the role in training of govern ment as employer, Sir Godfrey considered the part played in training by government as government.

The main role of government is that of supplementing the efforts of industry and the professions themselves. Government, as government, only trains directly where there is a special and pressing need in the national interest and where the government has a special obligation. Apart from this, government's activities are confined to seeing that the necessary facilities for training are available to industry and the professions, and, where necessary, to assisting in the provision of those facilities.

Direct training given by government, as government, has always been limited to adults. The need for government to train adults for skilled crafts first arose in an acute form towards the end of the First World War, when large numbers of ex-service men could not return to their pre-war jobs because of their disabilities. Afterwards, when these schemes for resettling disabled ex-service men came to an end, vocational training was given to younger unemployed men in areas of heavy unemployment to equip them for fresh employment. In addition, training courses were given to those needing them as a result of prolonged unemployment in order to rehabilitate them-to make them physically fit to take a job. All this training took place in government training centres.

With the possibility of war a change in the nature of the training took place in 1938, and, from this date, the main object of the sixteen training centres was to train men and women for the engineering and allied industries.

After the outbreak of war in 1939, there was a wide extension of training in the government training centres. During the war years, 270,000 men and 150,000 women were given training courses of one kind or another. The great majority were for the munition industries; but 48,000 were for coal-mining and 56,000 were service tradesmen for the Armed Forces. The bulk of the training was of a semi-skilled nature; but much of it was of a highly skilled nature and many skilled tradesmen were given higher-grade training.

At the end of the War another change took place in the training scheme, which was redesigned to achieve two objects : first, to provide a resettlement scheme giving training in a large number of crafts to men and women whose careers had been disrupted by war service, whether that war service was with the Armed Forces or on civilian war work ; secondly, to train men and women to meet shortages of labour in trades of national importance. Such shortages were at first most marked in the building industry, and in the immediate post-war years the principal emphasis was placed on training for the main building crafts. Towards the end of 1947 , as a result of cuts in capital investment, training in the building trades was curtailed and limited to disabled persons, although there still continues to be a shortage in some of the crafts in many areas. At the same time, facilities were expanded for training in a number of other trades of national importance.

The new rearmament programme may cause a further change, and it would appear that government training centres will again be required to train men and women as semi-skilled operatives for those industries that will have to expand, and also to undertake some higher-grade training to increase the supply of very highly skilled men.

Government has also recognized through the Disabled Persons (Employment) Act that it has a special obligation for all disabled persons, whether disabled by war service, by accident or from birth. This Act empowered the Minister of Labour to set up training courses for those disabled men and women who need to acquire new skills to be resettled in suitable employment ; it also empowered the Minister to set up Rehabilitation Units to assist disabled persons to re-establish their self-confidence and regain their working capacity.

Training courses are in operation at government training centres, at technical colleges and in employers' establishments where disabled persons over the age of sixteen are given intensive courses, in a range of some 140 skilled crafts, while individual training is arranged for other skilled work. In special cases training for semi-skilled employment is also arranged, provided it offers a good prospective of permanent resettlement to the individual disabled person.

For severely disabled persons training is given in residential colleges run by voluntary organizations and aided by government grants. Special arrange. ments for the training of blind persons are made in collaboration with the various interests concerned with the welfare of blind persons. The government has also set up a corporation-Remploy, Ltd.to employ the more severely disabled in special factories.

Another scheme of a special nature, aided by government grants, was designed to assist the resettlement in civil life of men and women whose education and training had been checked by war service in the Forces or by work of national importance. This was known as the Further Education and Training Scheme and, under it, about 150,000 men and women have been helped to complete their university education or to resume and complete their professional training.

Yet another special training scheme was the business training scheme for ex-service men. This scheme was designed to make good the gap caused by the War in the intake of executives and managers into industry and commerce. The training was in two parts : first, a three-month course of theoretical study at a technical college, devised with the general idea of telling the trainees what business was about and giving them some conception of the problems and opportunities before them; the second part of the course consisted of practical training with a firm, lasting from six months to two years according to the nature and size of the business. Provision was also made for such part-time study as the firm considered necessary during the period of practical training. The scheme, which was highly selective, proved very successful and gave great satisfaction both to the firms who co-operated and to the young men and women themselves. Altogether, training was given to about 6,500 persons, the great majority 
of whom were given immediate employment at managerial, administrative or executive level.

Sir Godfrey also referred to the Ministry of Labour Training within Industry Scheme. The purpose of the Scl.eme is to train supervisors-and this includes anyone in an organization who directs the work of others, and thus covers all levels of management. The Scheme is concerned with the development of threg skills-skills of instructing, of leadership and of improvement of methods. These skills, each of the greatest importanco in effective supervision, are common to all supervisors at all levels, irrespective of the industry, business or service in which they happen to be employed.

During the past six years the Ministry of Labour has trained about 2,200 trainers for various types of establishment in one or more of its three programmes, and some 2,700 establishments have adopted Training within Industry in some form.

The second lecture in the Cantor series was given by Dr. A. G. Beverstock, education officer to the Southern Electricity Board, who described in detail the training arrangements being developed in his organization.

He was followed by Mr. F. H. Perkins, education officer to Imperial Chemical Industries, Ltd., who made a similar statement about his undertaking. Mr. Perkins also elaborated four principles on which training should be based. Formal training, he suggests, is only a means to an end and must be very closely linked in form and duration to a particular need. The justification for its existence and its continued use must rest firmly on the assessment of results. It costs money, it absorbs skilled manpower, and it must be assessed in the same way as any other business operation may have to be assessed, although it must be recognized that the evaluation is often an extremely difficult problem. Secondly, although promotion prospects may often be linked with the objects of a training course, training schemes should help to increase interest and improve performance in the present occupations. There should be no passports to promotion attached to any training schemes; men must normally be promoted on the basis of performance on the job and not on ability as students in a training course. The development of greater ability at the present job should in itself enhance the prospects of promotion. Thirdly, training should be primarily concerned in helping those who are prepared to help themselves, and this applies at all levels, from the youngest upwards. The continuation of company assistance in any educational and training activities inside or outside the works or offices must be linked with a keenness on the part of the individual to pursue those opportunities and the ability he displays in profiting by them. Fourthly, a company's training activities must uphold the principle of equality of opportunity. Schemes that give outstanding advantage to some and not to others may lead to discontent and a sense of injustice. The objective must be to help in opening the door to all those who possess the necessary potential but who might otherwise not get the chance.

Under the general heading of training for the professions, Sir Harold Howitt considered the training of accountants, and declared himself firmly against any system of part-time release whereby student accountants could attend educational classes.

The last lecture in the series was given by Mr. Thomas E. Scott, who discussed the training of architects. There are two main methods of training for the architectural profession : pupilage or office training with part-time instruction at day or evening schools, and full-time training in a recognized school. Those who adopt the former course are examined at intermediate and final stages by the Royal Institute of British Architects, while those who adopt the latter are examined in their own schools, degrees and diplomas being awarded on the joint recommendation of internal and external examiners.

T. H. HAWKINS

\section{ABRASION AND WEAR}

\section{SYMPOSIUM AT DELFT}

THE Rubber-Stichting at Delft celebrated the opening of its new administrative and laboratory buildings by convening an international symposium on "Abrasion and Wear", which was held in the new and well-appointed lecture theatre of this institution during November 14-15. The attendance at the meeting had been limited to about a hundred and fifty participants, fifty-three of whom came from countries outside the Netherlands. The twenty-six British visitors formed the largest single foreign contingent. Altogether, eleven nations were represented at the symposium, which could thus fairly claim to be international. The proceedings of the symposium, which was conducted exclusively in English, consisted of eight lectures of forty minutes each, followed by twenty minutes of discussion. They are being published in Engineering and will later be available in book form.

The Rubber-Stichting, like its sister organizations, the British Rubber Producers' Research Association in Welwyn Garden City and the Institut Français du Caoutchouc in Paris, is primarily engaged in the study of natural rubber and in promoting its use. The symposium, however, covered a much wider field of materials and ranged from the mode of action of extreme-pressure lubricants to the wear of cotton shirts. A similar variety of interests was represented by the exhibition of abrasion testing apparatus which had been arranged in the exhibition hall of the Rubber-Stichting. Both general-purpose abrasion. machines and special instruments were shown, as, for example, an abrader intended for the testing of wood for clogs under realistic conditions. The largest exhibit was a machine to test model tyres on a rotating abrasion track of concrete. This is a venture of the Rubber-Stichting and is still in the experimental stage. During one of the lunch intervals, an informal discussion took place to give all those who were interested in the testing aspect of abrasion an opportunity of exchanging views on the usefulness or otherwise of the various machines and techniques.

The symposium was opened by Dr. R. Houwink, director-general of the Rubber-Stichting. In welcoming the participants, he stressed that the aim of the organizers of the meeting had been to bring together workers in hitherto unrelated fields of abrasion and wear, so that they could hear about each other's work and benefit from each other's experience. Dr. H. C. J. de Decker, director of research of the Rubber-Stichting, then took over as chairman and presided over the meeting with commendable firm. 